\title{
Kecerdasan Anak Usia Dini Ditinjau Dari Prespektif Teori Kecerdasan Howard Gardner
}

\author{
Kezia Vb Lalujan, Olivia Krismayani, Teddy Y. Manajang
}

\begin{abstract}
Abstrak
Teori kecerdasan Gardner mengatakan bahwa tidak ada manusia yang tidak cerdas. Bagi Gardner tidak ada anak yang bodoh atau pintar; yang ada adalah anak yang menonjol dalam salah satu atau beberapa jenis kecerdasan. Tetapi terkadang di sekolah atau di rumah, guru atau orang tua mengatakan anaknya tidak pintar atau bodoh dan inilah yang terkadang membuat seorang anak menjadi patah semangat, down, dan tidak mau belajar lagi sehingga susah untuk mencapai masa depan yang baik. Tujuan penulisan ini untuk memberikan teguran atau ajaran kepada guru dan orang tua supaya tidak mengatakan kepada anaknya bahwa mereka bodoh atau tidak pintar tetapi selayaknya orang tua dan guru jeli dan cermat merancang sebuah metode khusus untuk mencari dan mengasah kecerdasan anaknya karena setiap manusia memiliki kelebihannya masing-masing, sehingga anak-anak mempunyai masa depan yang baik. Dengan menggunakan teori-teori dari berbagai sumber dan di analisis sehingga menemukan teori untuk memecahkan suatu masalah. Teori Gardner mengatakan bahwa tidak ada manusia yang tidak cerdas dan tidak ada anak yang bodoh dan pintar. Setiap manusia memiliki kelebihan masing-masing, jadi guru dan orang tua seharusnya bisa melihat dengan jeli dan cermat sehingga bisa merancang sebuah metode khusus untuk mencari dan mengasah kecerdasan anaknya sehingga anak-anak memiliki masa depan yang baik.
\end{abstract}

Kata-kata kunci: Analisis, kecerdasan anak usia dini, kecerdasan menurut Howard Gardner.

\section{Pendahuluan}

Pendidikan merupakan indikator penting dalam proses perkembangan dan perwujudan individu, utamanya dalam hal pembangunan bangsa dan negara. Menilai sebuah kemajuan suatu budaya sangatlah bergantung pada bagaimana mengenali, menghargai, dan memanfaatkan sumber daya manusia. Manusia dikenal sebagai makhluk Tuhan yang paling cerdas. Kecerdasan yang dimiliki manusia menempatkannya sebagai sebaik-baik ciptaan Tuhan. Sayangnya berbagai potensi dasar kecerdasan manusia yang sangat banyak tersebut, kurang tergali secara optimal. Salah satu upaya optimalisasi kecerdasan itu adalah dengan mengembangkan seluruh potensi kecerdasan yang dikenal dengn keerdasan majemuk. Kecerdasan majemuk adalah sebuah konsepsi kecerdasaan yang saat ini menjadi perhatian para ahli, salah satunya ada Howard Gardner.Anak adalah manusia kecil yang memiliki potensi yang masih harus dikembangkan. Anak 
memiliki karakteristik tertentu yang khas dan tidak sam dengan orang dewasa, mereka selalu aktif, dinamis, antusias dan ingin tahu apayang dilihat,didengar, dirasakan.Anak usia dini adalah sosok individu yang sedang menjalani suatu proses perkembangan dengan pesat. Berdasarkan Undang-Undang Nomor 20 Tahun 2003 tentang Sistem Pendidikan Nasional berkaitan dengan Pendidikan Anak Usia Dini tertulis pada pasal 28 ayat 1 yang berbunyi "Pendidikan Anak Usia Dini diselenggarakan bagi anak sejak lahir sampai dengan umur enam tahun dan bukan merupakan prasyarat untuk mengikuti pendidikan dasar." ${ }^{1}$ Prinsip yang terpenting dari perkembangan kecerdasan anak usia dini adalah anak dapat belajar dari hal-hal yang sederhana sampai yang luas, dari suatu yang konkrit beralih memahami sesuatu yang abstrak dan dari interaksi terhadap diri sendiri beranjak untuk berinteraksi dengan orang lain disekitarnya. ${ }^{2}$ Anak akan belajar dengan baik apabila kebutuhan fisiknya terpenuhi dengan optimal serta merasa aman dan nyaman di lingkungan sekitarnya. Anak belajar terus-menerus dengan konsep bermain yang terarah sesuai dengan keinginannya, dimulai dari membangun pemahaman tentang sesuatu, kemudian mengeksplorasi lingkungan, menemukan kembali tentang sebuah konsep, hingga mampu membuat sesuatu yang berharga berupa karya dari pemahaman yang dimilikinya. Setelah pemahaman didapat, anak belajar melalui interaksi sosial, baik dengan orang dewasa maupun dengan teman sebayanya sebagai pengembangan dari kecerdasan interpersonal yang dimilikinya. Sehingga minat dan ketekunan anak senantiasa memotivasi belajar anak dalam berbagai keadaan. Hal yang malatarbelakangi standar kecedasan dan gagasan rasionalisme, dimana kecerdasan manusia hanya ditinjau dari skala tingkat IQ yang tertinggi. Oleh karenanya, Gardner seorang psikolog dan ahli pendidikan dari Universitas Harvard merumuskan teorinya tentang multiple intelligences dan membuat riset dengan mmeberikan contoh nyata bahwa orang yang sukses dalam hidupnya tidak hanya mengandalkan IQ tertinggi saja melainkan membutuhkan kecerdasan-kecerdasan lainnya. ${ }^{3}$

Dalam multiple inteligences, Howard Gardner dari Harvard menyatakan bahwa sedikitnya ada tujuh macam kecerdasan, termasuk kecerdasan musical, sosial, kinestetis, rasional, dan emosional. Namun dalam buku ini saya menyatakan bahwa semau kecerdasan kita, yang jumlahnya mungkin tak terbatas, dapat dihubungkan dengan salah satu dari ketiga sistem saraf dasar yang terdapat didalam otak. Bahkan semua jenis kecerdasan yang disebut Gardner pada hakikatnya adalah varian dari ketiga kecerdasan utama IQ, EQ, dan SQ serta pengaturan saraf ketiganya. ${ }^{4}$ Bagi anak-anak, khususnya anak usia dini masih mempunyai peluang yang cukup besar untuk mengembangkan dan memiliki berbagai kecerdasan. Karena pada masa tersebut merupakan saat yang paling penting untuk pembentukan kecerdasan anak. Selain itu, pendidikan yang tepat juga dapat menentukan kecerdasannya. Menurut Gardner sebagaimana dikutip Mulyasa, anak usia dini memegang peranan yang sangat penting karena perkembangan otak manusia mengalami lompatan

\footnotetext{
${ }^{1}$ HASFA HANDAYANI, "UPAYA MENINGKATKAN KECERDASAN ANAK USIA DINI DENGAN MENGGUNAKAN TEORI MULTIPLE INTELEGENCE DI TAMAN KANAKKANAK (TK) 'AISYIYAH BUSTANUL ATHFAL 62 KENDANGSARI KECAMATAN TENGGILIS MEJOYO SURABAYA,” t.t.

${ }^{2}$ M. Zakaria Hanafi, Ma.Pd., Implementasi Metode Sentra Dalam Pengembangan Kecerdasan Majemuk Anak Usia Dini, 2019 Ed. (Yogyakarta: Deepublish (Grup Penerbitan Budi Utama), 1.

${ }^{3}$ Ibid, 4.

${ }^{4}$ Danah Zohar Dan Ian Marhall, Sq - Kecerdasan Spiritual, 2007 Ed. (Bandung: Mizan), 4.
} 
berkembang sangat pesat, yakni mencapai $80 \%$. Ketika dilahirkan di dunia, anak manusia telah memncapai perkembangan otak 25\%, sampai usia empat tahun perkembangannya mencapai $50 \%$, dan sampai delapan tahun mencapai $80 \%$, selebihnya berkembang sampai usia 18 tahun. ${ }^{5}$

\section{Kajian Teori}

\section{Latar Belakang Kecerdasan Majemuk Menerut Howard Gardner}

Dikotomi anak cerdas dan tidak cerdas, serta pemberian label hiperaktif, gangguan belajar, dan prestasi di bawah kemampuan, mendorong para pendidik untuk mepelajari teori Multiple Intelligences. Setelah menemukan delapan bukti dari teorinya, Gardner meneguhkan criteria temuannya tentang Sembilan kecerdasan dalam multiple intelligences. Howard Gardner (1993; Armstrong, 1993) menyadari bahwa banyak orang bertanya-tanya tentang konsep multiple intelligences. ${ }^{6}$

Kecerdasan majemuk adalah istilah yang digunakan Howard Gardner untuk menunjukkan bahwa pada dasarnya manusia itu memiliki banyak kecerdasan, tidak hanya sebatas IQ seperti yang di kenal selama ini. Menurut Gardner, setidaknya ada sembilan kecerdasan yang dimiliki oleh manusia yaitu kecerdasan linguistik, kecerdasan matematis-logis, kecerdasan ruang visual (spasial), kecerdasan kinestetik badani, kecerdasan musikal, kecerdasan antar pribadi, dan kecerdasan intra pribadi, kecerdasan naturalis, dan kecerdasan eksistensial. Kesembilan kecerdasan tersebut ada pada setiap individu dan perlu dikembangkan secara maksimal sehingga siswa yang dalam beberapa kecerdasan kurang menonjol dapat dibantu serta dibimbing untuk mengembangkan dan meningkatkan kecerdasannya dalam hal ini pendidikan melalui metode pembelajarannya merupakan pihak yang bertanggung jawab untuk mengembangkannya. ${ }^{7}$

Di dalam teorinya Gardner menjelaskan bahwa setiap manusia/ seseorang dianugerahi lebih dari satu intelegensi dengan bentuk kemampuan yang berbedabeda kemudian disebutnya dengan multiple intelligence (kecerdasan majemuk). Pengertian inteligensi menurut Gardner ini berbeda penafsiran dengan pengertian yang dipahami sebelumnya. Sebelum Gardner, pengukuran intelligence question (IQ) seseorang dipatok berdasar pada tes IQ saja, yang mana hanya menonjolkan kecerdasan matematis-logis dan linguistik saja. Sehingga kecerdasan pada bidang yang lain kurang diperhatikan. Hasil penemuan Gardner tentang inteligensi manusia berefek mengubah konsep dalam kecerdasan. Yaitu, Inteligensi seseorang dapat dikembangkan dengan melalui pendidikan dan berjumlah banyak. ${ }^{8}$

Sebagian orangtua sering mengeluhkan dan merasa bahwa anak mereka kurang cerdas bahkan termasuk lambat belajar. Standar atau patokan yang digunakan biasanya berdasarkan prestasi belajar yang didapat di bangku sekolah. Namun

\footnotetext{
${ }^{5}$ M. Fadiilah, M.Pd.I., Buku Ajar Bermain dan Permainan Anak Usia Dini, 2017 ed. (Jakarta: Prenadamedia Grup), 1.

${ }^{6}$ Tadkiroatun Musfiroh, M.Hum., "Hakikat Kecerdasan Majemuk (Multiple Intelligences)," t.t.

${ }^{7}$ Muhammad Ibrahim Rahman, "Metode Pembelajaran Berbasis Kecerdasan Majemuk (Multiple Intelligences) terhadap Siswa," t.t, 4.

${ }^{8}$ Ibid, 7.
} 
demikian, para orangtua lupa bahwa hampir seluruh aspek yang dinilai dalam dunia pendidikan kita masih berpusat pada kemampuan kognitif atau intelektual semata. ${ }^{9}$

Gardner menentang pendidikan sekolah dan pemikiran sains kuno yang mengatakan orang-orang dilahirkan dengan kemampuan kognitif umum yang dapat dengan mudah diukur dengan tes jawaban singkat. Sebaliknya, Multiple Intelligencesanggup memberikan teori baru dengan beberapa jenis kecerdasan yang bisa mencerminkan berbagai cara untuk berinteraksi dengan dunia. Setiap orang memiliki perpaduan kecerdasan yang unik ini. ${ }^{10}$ Menurut penelitian Howard Gardner (seorang psikolog dan ahli pendidikandari Universitas Harvard, AmerikaSerikat), di dalam diri setiap anak tersimpan. Sembilanjenis kecerdasan yang siap berkembang. Ia memetakan lingkup kemampuan manusia yang luas tersebut menjadi Sembilan kategori yang komprehensif atau Sembilan macam kecerdasan dasar. Sembilan jenis kecerdasan tersebut disebut Multiple Intelligences atau kecerdasan majemuk (kecerdasan ganda). ${ }^{11}$

1. Kecerdasan linguistik (Linguistic intelligence) adalah kemampuan untuk menggunakan dan mengolah kata-kata secara efektif baik secara oral maupun secara tertulis.

2. Kecerdasan matematis-logis (Logical -mthematical intelligence) adalah kemampuan yang berkaitan dengan penggunaan bilangan dan logika. Jalan pikiran bernalar dengan mudah mengembangkan pola sebab akibat.

3. Kecerdasan ruang (Spatial intelligence) adalah kemampuan untuk menangkap dunia ruang visual secara tepat dan kemampuan untuk mengenal bentuk dan benda secara tepat serta mempunyai daya imaginasi secara tepat.

4. Kecerdasan kinestetik-badani (bodily-kinesthetic intelligence) adalah kemampuan menggunakan tubuh atau gerak tubuh untuk mengekspresikan gagasan dan perasaan.

5. Kecerdasan musikal (Musical intelligence) adalah kemampuan untuk mengembangkan, mengekspresikan, dan menikmati bentuk-bentuk music dan suara, peka terhadap ritme, melodi, dan intonasi serta kemampuan memainkan alat musik.

6. Kecerdasan interpersonal (Interpersonal intelligence) adalah kemampuan untuk mengerti dan menjadi peka terhadap perasaan, intensi, motivasi, watak, temperamen orang lain. Kemampuan yang menonjol dalam berelasi dan berkomunikasi dengan berbagai orang.

7. Kecerdasan intrapersonal (Intrapersonal intelligence)adalah kemampuan yang berkaitan dengan pengetahuan akan diri sendiri dan kemampuan untuk bertindak secara adaptif berdasar pengalaman diri serta mampu berefleksi dan keseimbangan

Hanafi: Pemilihan Profesi Berdasarkan.......diri, kesadaran tinggi akan gagasan-gagasan. Mereka mudah berkonsentrasi dengan baik, suka bekerja sendiri dan cenderung pendiam.

${ }^{9}$ R. Rachmy Diana, "SETIAP ANAK CERDAS! SETIAP ANAK KREATIF! Menghidupkan Keberbakatan dan Kreativitas Anak," Desember2006, No. 2, Vol.3 (t.t.), 123.

${ }^{10}$ Hanafi, "Pemilihan Profesi Berdasarkan Kecerdasan Majemuk (Multiple Intelligence)," 1 Januari-Juni 2016 Volume 3 (t.t.).

${ }^{11}$ Ibid, 7-8. 
8. Kecerdasan lingkungan/naturalis (Naturalist intlligence) adalah kemampuan untuk mengerti flora dan fauna dengan baik, menikmati alam, mengenal tanaman dan binatang dengan baik.

9. Kecerdasan eksistensial (Exixtentialintlligence) adalah kemampuan menyangkut kepekaan dan kemampuan seseorang untuk menjawab persoalan-persoalan terdalam keberadaan atau eksistensimanusia.

\section{Penerapan Model Pembelajaran Dalam Proses Pembelajaran Peserta Didik Berusia Dini}

Masa anak-anak merupakan masa dimana semua perkembangan baik kognitif maupunfisik berkembang secara cepat. Sekitar $80 \%$ anak dapat menunjukkan perkembangannya secaramaksimal. Perkembangan Fisik merupakan perkembangan yang sangat cepat, dan orang tuadapat memberikan stimulasi yang lebih agresif pada anak, sehingga seluruh kemampuan fisikanak dapat berjalan optimal sesuai dengan perkembangannya. Perkembangan dapat dimaknaisebagai suatu gejala dimana kecerdasan anak akan mulai tampak, walaupun derajatkecerdasannya berbeda-beda. Kecerdasan adalah satu hal bahwa terdapat orang-orang pandaiyang dapat diharapkan tampil dengan baik dalam berbagai jenis situasi pembelajaran (Robert E.Slavin, 2008: 163). Menurut Gardner, manusia memiliki semua kecerdasan, walau dengan derajat yang beragam. Masing masing orang mungkin memiliki satu kecerdasan dominan dankecerdasan sekunder yang digunakan dalam mencerap, mengingat dan penerapan pembelajaran (Agus Nggermanto, 2001: 208). Multiple Intelligences yang dalam bahasa Indonesia diterjemahkan sebagai kecerdasanmajemuk atau kecerdasan ganda merupakan salah satu teori kecerdasan yang memperolehbanyak pengakuan akhir-akhir ini. Multiple intelegency adalah sebuah penilaian yang melihatsecara deskriptif bagamana individu menggunakan kecerdasanya untuk memecahkan masalahdan menghasilkan sesuatu (Yuliani Nurani Sujiono, 2009: 183). Teori ini dicetuskan olehHoward Gardner, psikolog dari Harvard yang telah menemukan 9 kecerdasan manusia. AsumsiMI muncul karena hasil penelitian Gardner yang memberikan gambaran bahwa individu dapatmencapai keberhasilan tidak hanya mengandalkan IQ tinggi namun juga didukung olehkecerdasan yang dikembangkan oleh seseorang tersebut. ${ }^{12}$

Seluruh aspek perkembangan dankemampuan anak usia dini dapat distimulasi melalui pembelajaran yang bersifat holistik dan terpadu. Pembelajaran bersifat terpadu (Integrated Learning) yaitu tidak mengajarkan bidang studi secara terpisah (Slamet Suyanto, 2003). Satu kegiatan dapat menjadi wahana belajar berbagai hal bagi anak. Belajar yang efektif jika dapat menggunakan seluruh pengetahuan dan potensi yang dimiliki anak. Semakin banyak keterlibatan indera anak semakin banyak anak memperoleh hasil belajar. Hal tersebut dikuatkan dengan pendapat Howard Gardner bahwa anak memiliki potensi berupa kecerdasan jamak. Kecerdasan anak akan berkembang secara optimal bila difasilitasi dengan baik dan

\footnotetext{
${ }^{12}$ Aip Saripudin, "STRATEGI PENGEMBANGAN KECERDASAN NATURALIS PADA ANAK USIA DINI," 1, 3 (Maret 2017).
} 
benar, melalui straJurnal Pendidikan Anak, Volume 1, Edisi 1, Juni 201262 tegi pembelajaran yang sesuai dengan karakteristik dan perkembangannya. Melengkapi pendapat tersebut menurut NAEYC (Amerika Serikat) dalam pembelajaran DAP (DevelomentallyAppropriate Practices). Slamet Suyanto (2003) menyatakan bahwa kegiatan pembelajaran disesuaikan dengan tingkat usia dalam kelompok usia maupun secara individual. Dengan pembelajaran DAP maka anak akan lebih mudah belajar dalam memperoleh pengalaman. Maka berbagai potensi yang dimiliki anak dapat dikembangkan sesuai dengan usia dan perkembangannya, sehingga semua perkembangan anak dapat terstimulasi dengan baik. ${ }^{13}$

Setelah mempelajari model pembelajaran berbasiskan kecerdasan majemuk,maka selanjutnya akan dibahas tentang penerapan model pembelajaran berbasis kecerdasan majemuk terhadap peserta didik berusia dini. Penerapan tersebut dapat dibagi dalam tiga aspek yaitu kognitif, afektif dan psikomotorik sebagai berikut: ${ }^{14}$

$>$ Pertama, secara kognitif dapat dijabarkan sebagai berikut: pertama, dapat menarik perhatian peserta didik. Proses pembelajaran yang tidak monoton atau bervariasi tentu akan menarik perhatian peserta didik. Perhatian yang dimaksud penulis di sini adalah keaktifan jiwa yang tertinggi, jiwaitu pun semata-mata tertuju kepada suatu obyek atau sekumpulan obyek

$>$ Kedua, secara afektif adalah motivasi. Menurut Djamarah, motivasi merupakan suatu kekuatan yang dapat mendorong seseorang untuk melakukan sesuatu perbuatan termasuk belajar. Seseorang akan berhasil dalam belajar, kalau pada dirinya sendiri ada keinginan untuk belajar.

$>$ Ketiga, secara psikomotorik. Perkembangan motoric merupakan salah satu faktor yang sangat penting dalam perkembangan individu secara keseluruhan. Melalui keterampilan motoric anak dapat menghiburdirinya dan memperoleh perasaan senang.

proses pembelajaran, seorang guru tidak boleh terpaku hanya pada satu jenis

kemampuan saja, sebab satu jenis kemampuan saja tidak cukup untuk menjawab persoalan-persoalan manusia secara menyeluruh. ${ }^{15}$ Penelitimenegaskanbahwasemuapotensi-potensi manusia dapat dimanfestasikan dalam kehidupan manusiadan yang paling dapat mendatangkan kebaikan, kemanfaatan dan kemashlahatan manusia. ${ }^{16}$

Kemandirian belajar adalah kemampuan mengelolapikiran, perilaku, danemosi, memantau perilaku sendiri, berinisiatif belajar dengan atau tanpa bantuan orang lain; mendiagnosa kebutuhan belajarnya sendiri, merumuskan tujuan belajar; mengidentifikasi sumber belajar yang dapat digunakannya; memilih dan menerapkan strategi belajar, danmengevaluasi hasil belajarnya (Hargis, 2000; Zumbrunn, Tadlock, \& Roberts, 2011: 4; Vohs \& Baumiester, 2011: 65, Zimmerman, 1990: 11). ${ }^{17}$ Aspek-aspek kemandirianbelajar menurut Songdan Hill (2007: 32) meliputi

\footnotetext{
${ }^{13}$ Siwi Widiastuti, "Pembelajaran Proyek Berbasis Budaya Lokal untuk Menstimulasi Kecerdasan Majemuk Anak Usia Dini,” seri 1, volume 1 (Juni 2012). Hal. 61-62.

${ }^{14}$ Evi Tobeli, M. Pd.K, "Model Pembelajaran Berbasis Kecerdasan Majemuk Dan Penerapannya Dalam Proses Pembelajaran Anak Usia Dini," T.T.

${ }^{15} \mathrm{Hj}$. Huraidah, S.Pd, "Penerapan Strategi Berbasis Kecerdasan Majemuk Dalam Pembelajaran Bahasa Indonesia," T.T, 17.

${ }^{16}$ Azis, "Perbandingan Kecerdasan Majemuk," Nomor 2, Volume 7 (Desember 2018).

${ }^{17}$ Margaretha Madha Melissa, "Pengembangan Perangkat Pembelajaran topik lingkaran berbasis Kecerdasan Majemuk Gardner Berorientasi Pada Prestasi Dan Kemandirian Belajar," Tahun Xl/Juli 2016, No. 02, T.T, 300.
} 
personal attributes, processes, dan learning context. Personal Attributesmerupakan aspek yang berkaitan dengan motivasi siswa, tanggung jawab siswa dalam hal belajar, penggunaan sumber belajar, dan strategi belajar.Processesmerupakan aspek yang berkaitan dengan otonomi proses pembelajaran yang dilakukan oleh siswa meliputi merancang belajar, memantau/memonitoring belajar, serta evaluasi pembelajaran.Learning Context merupakan faktor lingkungan dan bagaimana faktor tersebut mempengaruhi tingkat kemandirian siswa.Dalam penelitian ini, aspek kemandirian belajar yang dimaksud adalah bertanggungjawab atas dirinya sendiri dalam belajar matematika, bernisiatif dalam belajar matematika, merancang belajar sendiri,danmemantau/monitoring dirinya sendiri dalam belajar matematika. ${ }^{18}$

Dalam dunia pendidikan, teori multiple intelligences mulai diterima karena dianggap lebih melayani semua kecerdasan yang dimiliki anak. Konsep MI menjadikan pendidik lebiharif melihat perbedaan, dan menjadikan anak merasa lebih diterima dan dilayani. Konsepini"menghapus" mitos anak cerdas dan tidak cerdas, karenamenurut konsep ini, semua anakhakikatnya cerdas. Hanya saja konsep cerdas itu perlu diredefinisi dengan landasan baru. ${ }^{19}$

Alasan kami menggunakan nas Alkitab dari Daniel 1:1-21, karena kecerdasan yang dimiliki oleh Daniel sepuluh kali lebih cerdas dari pada semua orang berilmu dan semua ahli jampi di seluruh kerajaan. Dan Daniel menggunakan kecerdasan kognitifnya yaitu pemahamannya untuk tidak memakan makanan Raja yang membuat ia najis, dan juga menggunakan kecerdasan psikomotoriknya untukbetulbetul tidak memakan makanan yang Raja siapkan, tetapi kecerdasan yang dimiliki oleh Daniel itu semua berasal dari Tuhan (Daniel 1:14). Dan pada zaman ini dipenuhi oleh kompetisi, baik itu anak-anak, dewasa, maupun orang tua untuk mencapai keberhasilan dalam kehidupan mereka.jadi jika kita memiliki kelebihankelebihan, dalam kecerdasan tertentu gunakanlah itu dengansebaik-baiknya, sehingga kita tidak merugikan diri sendiri maupun orang lain, dan semuan yaitu hanya untuk kemuliaan nama Tuhan.

Hubungan dari nas tersebut dengan teori yang digunakan ialah, bahwa tidak ada manusia yang tidak cerdas, dan kecerdasan yang dimiliki setiap manusia, semuanya itu berasal dari Tuhan dan di dalam Daniel 1:1-21, Daniel memiliki kecerdasan yang sangat luar biasa, yang berasal dasri Tuhan dan ia menggunakan kecerdasan itu dengan penuh hikmat dan bijaksana.

\section{Metode}

Metode penulisan makalah ini adalah analisis data kualitatif yaitu menjelaskan data-data yang dikumpulkan sesuai dengan teori-teori yang dirangkum dari hasil penelitian. ${ }^{20}$ Selanjutnya dengan menggunakan model pembelajaran

\footnotetext{
${ }^{18}$ Margaretha Madha Melissa, "Pengembangan Perangkat

Pembelajarantopiklingkaranberbasis Kecerdasan Majemuk Gardner Berorientasi Pada Prestasi Dan Kemandirian Belajar," Tahun Xl/Juli 2016, No. 02, T.T, 300.

${ }^{19}$ Muhibuddin Fadhli, "Pemikiran Howard Gardner Dalam Pendidikan Anak Usia Dini," September 2016, . No.1, Vol.1 (T.T.), 85.

${ }^{20}$ Hengki Wijaya dan Helaluddin Helaluddin, Analisis Data Kualitatif Sebuah Tinjauan Teori \& Praktik (Makassar: Sekolah Tinggi Theologia Jaffray Makassar, 2019).
} 
kooperatif berbasis media sosial. ${ }^{21}$ Dengan menggunakan metode 5P (Belajar berarti berubah) $)^{22}$ dengan tujuan untuk meningkatkan nilai-nilai karakter pada kecedasan anak usia dini. ${ }^{23}$

\section{Usaha Yang Tidak Biasa}

Fokus: bagaimana peserta kegiatan belajar dapat berpikir, dan bertindak setelah mengalami sendiri Firman Tuhan tersebut.

1. Penghubung: pengalaman yang tidak biasa

Sebelum memulai pembahasan, kelas dibuka dengan bermain games "logika".

Narator akan membacakan Firman Tuhan dari Daniel 1:6-20. Selama mendengar cerita ini pikirkan, rasakan, dan lakukan bagian Firman Tuhan tersebut.

Silahkan dengarkan Firman Tuhan sebagai petunjuk drama.

Ceritakanlah: bagaimana pendapat saudara tentang kejadian di peristiwa dalam cerita itu?

2. Pelajaran: usaha yang tidak biasa

Ceritakanlah usaha yang tidak biasa yang dilakukan oleh Daniel secara berpasangan, dan tuliskan pada sticky note kata kunci untuk menunjukan usaha Daniel tersebut. tempelkan sticky note di depan.

Mengapa Daniel itu berketetapan untuk tidak menajiskan dirinya dengan santapan raja dan dengan anggur yang biasa diminum raja? diskusikan dalam kelompok, dan catatkan pada kertas apa A4.

\section{Penerapan: pikiran, perasaaan, dan tindakan}

Dalam kelompok berdiskusi, apa saja yang saudara pikirkan, rasakan, dan lakukan apabila saudara mengalami situasi seperti itu. Tuliskan pada sticky note, lalu tempelkan di kertas lebar yang ada di depan sesuai dengan petunjuknya.

\section{Perubahan: bertindak sekarang}

Tuliskan komitmen saudara pada sticky note untuk melakukan usaha yang tidak biasa seperti dilakukan oleh Daniel tersebut, dan tempelkan pada Alkitab saudara pada nas tersebut.

\section{Penutupan}

${ }^{21}$ Hengki Wijaya dan Arismunandar Arismunandar, "Pengembangan Model Pembelajaran Kooperatif Tipe STAD Berbasis Media Sosial,” Jurnal Jaffray 16, no. 2 (6 Oktober 2018): 175-96, https://doi.org/10.25278/jj71.v16i2.302.

${ }^{22}$ Roland Walker, "Learning that LASTS," t.t., https://wycliffe.fi/wpcontent/uploads/2018/12/intro-to-learning-that-lasts-walker.pdf.

${ }^{23}$ Hengki Wijaya dan Helaluddin Helaluddin, "Hakikat Pendidikan Karakter," 2018, https://repository.sttjaffray.ac.id/id/publications/269450/hakikat-pendidikan-karakter. 
Nyanyikan lagu "Dalam Yesus (kekuatan dihidupku)" sebagai doa kita kepada Tuhan.

Kekuatan dihidupku

Kudapat dalam Yesus

Dia tak pernah tinggalkan ku

Setia menopangku, berseru

Berharap dalam Yesus

Reff: Ajaib kau Tuhan penuh kuasa

Sanggup pulihkan keadaanku

Dalam tanganMu seluruh hidupku

Tak akan goyah selamanya

Tujuan pembelajaran ini dengan teori kecerdasan yaitu, agar peserta mengerti bahwa tidak ada manusia yang bodoh, semua manusia telah diberikan kemampuan atau talenta masing-masing orang yang berasal dari Tuhan. Selain itu, peserta mengerti juga bahwa, melalui kecerdasan itu, manusia tidak boleh sombong atau mementingkan diri sendiri.

\section{Hasil dan Pembahasan}

Dari penerapan 5P yang telah dilakukan di dalam kelas kepada peserta maka peneliti memiliki hasil dari pengamatan dan aktivitas peserta adalah; sebagai pembuka kelas peneliti memberikan pertanyaan-pertanyaan logika, pertayaannya seperti "Saya memiliki 5 jari tetapi saya tidak hidup, siapakah aku?" dan pertanyaanpertanyaan logika lainnya. Dari perntayaan-pertanyaan yang diberikan kepada peserta, semua peserta dapat menjawab semua pertanyaan dengan baik dan ini membuktikan bahwa mereka semua memiliki kecerdasan matematis-logis. Langkah pertama yang dilakukan adalah drama tentang kisah Daniel yang diambil dari kitab Daniel 1:6-20 dan mengikut sertakan beberapa peserta untuk mendramakan dari kitab Daniel 1:6-20. Selama drama berlangsung peneliti membaca kisah tersebut dan para partisipan yang bermain drama mempraktekan kisah tersebut dan para peserta mendengarkan dan menyaksikan drama tersebut. Setelah drama selesai, peserta memberikan pendapat mereka masing-masing dari drama yang sudah di praktekkan di depan kelas, dan masing-masing jawab mereka berbeda-beda sesuai dengan pemahaman mereka dalam kelompok.

Pada langkah pelajaran, peserta dalam kelompoknya di berikan sticky note dan mereka menuliskan pendapat mereka tentang usaha yang tidak biasa yang dilakukan oleh Daniel, setelah itu sticky note tersebut di tempelkan di depan papan tulis. pertanyaan yang kedua yaitu, Mengapa Daniel itu berketetapan untuk tidak menajiskan dirinya dengan santapan raja dan dengan anggur yang biasa diminum raja? Dari pertanyaan tersebut mereka mendiskusikannya dalam kelompok dan menulisnya pada kertas kuning yang telah dibagikan, setelah itu mereka mengemukakan pendapat mereka setiap kelompok.

Dalam langkah penerapan, setiap kelompok berdiskusi tentang apa yang dipikirkan, rasakan, dan lakukan apabila mereka mengalami situasi seperti yang 
dialami oleh Daniel. Setelah itu mereka tuliskan pada sticky note, lalu per kelompok membacakan hasil diskusi mereka.

Pada langkah perubahan, setiap orang dibagikan sticky note dan menuliskan komitmen tentang usaha apa yangdapat mereka lakukan seperti yang dilakukan oleh Daniel, dan sticky note tersebut di tempelkan di dalam Alkitab mereka masingmasing, sesuai dengan nats Daniel 1:1-21.

Pada langkah yang terakhir peneliti, menjelaskan kembali tentang kisah Daniel dan hubungannya dengan kecerdasan Gardner, sehingga peserta dapat lebih mengerti kembali tentang kecerdasan Gardner. Setelah itu peneliti memberi kesimpulan dari pembelajaran tentang kisah Daniel. Selanjutnya peneliti mempersilahkan peserta untuk berdiri, dan menyanyikan sebuah lagu "Dalam Yesus" sebagai doa mereka kepada Tuhan, dan setelah bernyanyi kelas di tutup dengan doa.

\section{Kesimpulan}

Pendidikan merupakan indikator penting dalam prosesperkembangan anak usia dini dan dapat menciptakan masa depan yang baik. Pendidikan tidak hanya dilakukan disekolah oleh guru kepada murid saja tetapi juga dirumah oleh orang tua kepada anaknya. Teori kecerdasan menurut Howard Gardner mengatakan tidak ada manusia yang tidak cerdas dan tidak ada anak yang bodoh dan pintar. Tetapi terkadang di sekolah bahkan dirumah guru dan orang tua mengatakan kepada murid atau anaknya bahwa mereka bodoh dan hal inilah yang membuat seorang anak atau murid down dan tidak mau belajar lagi. Semestinya guru dan orang tua harus mendukung anaknya dengan cara mencari dan mengasah kemampuan yang dimiliki anaknya. Teori Kecerdasan Gardner mengatakan kecerdasan manusia tidak hanya kecerdasan IQ saja tetapi ada 9 kecerdasan yaitu kecerdasan linguistik, kecerdasan matematis-logis, kecerdasan ruang visual (spasial), kecerdasan kinestetik badani, kecerdasan musikal, kecerdasan antar pribadi, dan kecerdasan intra pribadi, kecerdasan naturalis, dan kecerdasan eksistensial. Setiap manusia memiliki kelebihan dan kecerdasannya masing-masing. Jadi jangan mengatakan bahwa ada anak yang bodoh karena setiap anak memiliki kecerdasannya masing-masing dan tugas guru dan orang tua adalah mencari dan mengasah kelebihan dan kecerdasan murid dan anaknya supaya dapat menciptakan masa depan yang baik buat anak, seperti seorang anak yang memiliki kecerdasan IQ yang kurang tetapi memiliki kecerdasan musical, dia bisa menjadi pemain musik yang hebat, tidak memiliki kecerdasan musical tetapi memilki kecerdasan kinestik, dia bisa menjadi olahragawan yang hebat.

Setiap manusia diberikan kelebihan dan kecerdasan masing-masing oleh Tuhan. Ada yang diberikan hanya satu kecerdasan atau kelebihan bahkan ada yang diberikan dua kecerdasan atau lebih lagi. Tetapi jangan menjadikan kecerdasan atau kelebihan yang dimiliki untuk kepentingan diri sendiri, sombong, dan menggunakannnya untuk hal yang salah tetapi menggunakan kecerdasan yang dimiliki untuk kebaikan dan kebenaran. Salah satu tokoh Alkitab yang dapat kita contoh adalah Daniel, Ia diberikan kelebihan dari Tuhan untuk menafsirkan mimpi dan Daniel menggunakan kelebihannya ini dengan baik dan benar. Daniel setia kepada Tuhan dengan tidak menajiskan dirinya. Daniel adalah orang yang takut akan Tuhan, rendah hati, dan tidak sombong. Jadi dengan kecerdasan atau kelebihan yang dimiliki jangan sombong, tetaplah rendan hati, dan tetap mengandalkan Tuhan. 


\section{KEPUSTAKAAN}

Aip Saripudin. "STRATEGI PENGEMBANGAN KECERDASAN NATURALIS PADA ANAK USIA DINI," 1, 3 (Maret 2017).

Azis. "PERBANDINGAN KECERDASAN MAJEMUK," Nomor 2, Volume 7 (Desember 2018).

Danah Zohar dan Ian Marhall. SQ - Kecerdasan Spiritual. 2007 ed. bandung: Mizan, t.t.

Hanafi. "PEMILIHAN PROFESI BERDASARKAN KECERDASAN MAJEMUK (MULTIPLE INTELLIGENCE)." 1 Januari-Juni 2016 Volume 3 (t.t.).

HASFA HANDAYANI. "UPAYA MENINGKATKAN KECERDASAN ANAK USIA DINI DENGAN MENGGUNAKAN TEORI MULTIPLE INTELEGENCE DI TAMAN KANAK-KANAK (TK) 'AISYIYAH BUSTANUL ATHFAL 62 KENDANGSARI KECAMATAN TENGGILIS MEJOYO SURABAYA," t.t.

Hj. HURAIDAH , S.Pd. "Penerapan Strategi Berbasis Kecerdasan Majemuk dalam Pembelajaran Bahasa Indonesia," t.t.

M. Fadiilah, M.Pd.I. Buku Ajar Bermain dan Permainan Anak Usia Dini. 2017 ed. Jakarta: Prenadamedia Grup, t.t.

M. Zakaria Hanafi, MA.Pd. IMPLEMENTASI METODE SENTRA dalam pengembangan kecerdasan majemuk anak usia dini. 2019 ed. yogyakarta: deepublish (Grup Penerbitan Budi Utama), t.t.

Margaretha Madha Melissa. "PENGEMBANGAN PERANGKAT PEMBELAJARANTOPIKLINGKARANBERBASIS KECERDASAN MAJEMUK GARDNER BERORIENTASI PADA PRESTASI DAN KEMANDIRIAN BELAJAR." Tahun XL/Juli 2016, No. 02, t.t.

Muhammad Ibrahim Rahman. "Metode Pembelajaran Berbasis Kecerdasan Majemuk (Multiple Intelligences) terhadap Siswa," t.t.

Muhibuddin Fadhli. "PEMIKIRAN HOWARD GARDNER DALAM PENDIDIKAN ANAK USIA DINI." September 2016, . No.1, Vol.1 (t.t.).

R. Rachmy Diana. "SETIAP ANAK CERDAS! SETIAP ANAK KREATIF! Menghidupkan Keberbakatan dan Kreativitas Anak." Desember2006, No. 2, Vol.3 (t.t.).

Siwi Widiastuti. "Pembelajaran Proyek Berbasis Budaya Lokal untuk Menstimulasi Kecerdasan Majemuk Anak Usia Dini," seri 1, volume 1 (Juni 2012).

Tadkiroatun Musfiroh, M.Hum. "Hakikat Kecerdasan Majemuk (Multiple Intelligences)," t.t.

Tobeli, M. Pd.K, Evi. "MODEL PEMBELAJARAN BERBASIS KECERDASAN MAJEMUK DAN PENERAPANNYA DALAM PROSES PEMBELAJARAN ANAK USIA DINI," t.t.

Walker, Roland. "Learning that LASTS," t.t. https://wycliffe.fi/wpcontent/uploads/2018/12/intro-to-learning-that-lasts-walker.pdf.

Wijaya, Hengki, dan Arismunandar Arismunandar. "Pengembangan Model Pembelajaran Kooperatif Tipe STAD Berbasis Media Sosial.” Jurnal Jaffray 16, no. 2 (6 Oktober 2018): 175-96. https://doi.org/10.25278/jj71.v16i2.302. 
Wijaya, Hengki, dan Helaluddin Helaluddin. Analisis Data Kualitatif Sebuah Tinjauan Teori \& Praktik. Makassar: Sekolah Tinggi Theologia Jaffray Makassar, 2019.

" "Hakikat Pendidikan Karakter," 2018.

https://repository.sttjaffray.ac.id/id/publications/269450/hakikat-pendidikankarakter. 